\title{
The Relationship between Key Economic Indicators of the Euro Area after the Financial Crisis
}

\author{
Ana-Maria Tepus ${ }^{1}$ and Adelina Toader ${ }^{2}$ \\ ${ }^{1}$ Academy of Economic Studies, Bucharest, Romania \\ ${ }^{2}$ Duisenberg School of Finance, Amsterdam, Netherlands
}

\begin{abstract}
Three years after the deepest recession of the last decades, it seems that many European policies still remain to be addressed and that the sense of causality between real economy and economic growth indicators has suffered alterations, which, if properly observed, can be used to predict future economic trends.

In a recent report, the IMF analyses the link between the weak balance sheets of governments and the banking sector, revealing new tensions in financial markets, particularly in the Euro area. Further on, ECB points out that it is crucial to integrate the monetary and fiscal policies, both at a national and EU level. Therefore, at a national level, a list of priorities would start with restoring public debt sustainability, increasing savings and enhancing potential growth. And at the EU level, fiscal consolidation should be undertaken in a way that would minimize its negative impact on the real economy. Moreover, monetary policies should be guided as to mitigate market volatility while ensuring banks' liquidity and efficient actions taken in order to eliminate weaknesses in balances sheets while safeguarding lending capacity.

By using econometric methods as Granger causality or panel-data regression, the researchers capture the interdependencies between the real economy and the financial market, considering the isolated influences of other factors like: effects of global financial crisis on monetary union, differences between Euro area countries, etc. The results show the existence of a bidirectional causality between stock market and monetary policy, while there is no causality between stock market and real economic growth.
\end{abstract}

Keywords: real economic growth, stock market, panel data regression, Euro area.

JEL Classification Codes: G01, E44, C23.

\section{Introduction}

At the moment, there are several research directions which focus on the link between the capital market and the real economy and claim (i) a strict unidirectional link, in both senses, (ii) a bidirectional connection, or (iii) the total absence of such a link. Developing economies have been pointed out in various empirical researches as hosting evidence of high influence posed on the real economy by the capital markets. Based on such studies, this research will focus on capturing the interdependencies between the real economy and the financial markets, considering the isolated influences of other factors such as: effects of global financial crisis on monetary union and differences between Euro areas. As proxy for the real economy performance, 
the researchers chose to look into the returns of the EURO-Stoxx 50 Index, which aggregates the top blue-chip companies, leaders over various sectors in the Euro-12 countries.

Taking into account that the interdependence between the financial markets has recently experienced mounting levels, Milani (2011) analyzed the impact of the capital market on the macro-economic variables of countries characterized by an open economy. The study concludes that the capital markets of the US and Germany have an influence on the macroeconomic variables of countries such as Australia, Canada, New Zeeland, Ireland, Austria and the Netherlands, which is brought by the cross-country wealth channel.

Also, in terms of unidirectional perspective from the capital economy towards the real economy, Cetin (2011) analyzed the relationship between the stock prices and inflation rate by using monthly data for the US economy for the 1983-2010 periods, chosing as variables the Thomson Reuter/Jeffries CRB Commodity Futures Index and Consumer Price Index- as a measure of inflation. The conclusion of this econometric technique is that there is a significant link between the stock prices and the inflation rate, but it is unidirectional as the inflation does not influence the fluctuations of the stock market.

Söhnke et al. (2007) use a time-varying copula model to investigate the impact of the introduction of the Euro on the interdependencies between seventeen European stock markets during the years 1994 to 2003; he shows that the market dependence increased after the Euro adoption only in large equity markets (such as: France, Germany, Italy, the Netherlands and Spain).

Raunig and Scharler (2010) investigate US economic data between 1960-2007 and found that an increasing level of volatility reflects a higher degree of uncertainty. Thus, the increase of the uncertainty level triggers the decrease of consumption and investments, of the aggregate demand and, finally, of the economic growth.

A small percentage of the studies dedicated to this correlation have shown a unidirectional causality, from the real economy towards the capital market. The argument is that economic growth leads to an increase in certain financial instruments' demand and that the markets adapt to the economy.

A negative unidirectional impact of the exchange rate on the returns of the US and the UK stock markets is found by Dimitrova (2005). Kilian and Park (2009) obtain the same result by looking into the oil price shocks impact on the US capital market.

Various studies underline the existence of a link between the real economy and the capital market dynamics. Shahbaz and Ali (2008) use ARDL models and Granger causality analysis to find a bidirectional, positive relationship between the two. Giannellis et al. (2008) use bivariate EGARCH $(2,1)$ models to find a significant bi-directional short-term linkage between the capital market and the real economy, for the US and UK in the late 1990s. Bjornland and Leitemo (2009) use the structural vector autoregressive (VAR) methodology to study the interdependence of the US monetary policy and S\&P 500 stock index, and conclude that there is a strong significant and bi-directional connection between the monetary policy and the stock prices.

There are a few studies demonstrating no significant relationship between the capital market and the real economy. Jamil (2010) looks into the performance of developing countries which, unlike that of the developed countries, is characterized by a bi-directional link between capital market and real economic growth indicators and concludes that the capital market volatility has a negative influence on the economic growth; whilst if this is compensated by high returns, the negative influence is not significant.

This global crisis reveals that international financial flows can grow very quickly and 
suddenly unwind_ potentially having an impact on economic growth, real exchange rates and current account position, and also on the stability of financial market (Cardareli et al., 2010). Ostry et al. (2010) show that financial flows tend to become more problematic as evidence emerges of currency overvaluation, excessive reserve accumulation, rising inflationary pressures and signals of housing and lending booms. The policy instruments dealing with financial flows include: monetary and fiscal policies, forms of capital controls, higher exchange rate flexibility and enhanced macroeconomic prudential measures. These tools are needed to reduce the possible risk and negative feedback effects between the financial and real sector.

Katrin Forster et al. (2011) propose policy actions, that could be used for a more efficient and sustainable allocation of cross-border flows and could reduce crosscountry and cross-sectorial financial vulnerabilities: more developed financial flows, including macroeconomic discipline and enhanced financial regulation and supervision.

Van Riert (2010), on the importance of macroeconomic discipline, suggests that the countries which ran high fiscal deficits prior to the crisis, are more affected by the crisis, thus they experience higher stock market volatility, have a lower ability to reestablish foreign investors` confidence and re-attract foreign capital.

In a recent publication, the IMF (2010) shows that the prudential regulation influences the nature and volume of crossborder financial flows, in a way that could help reduce uncertainty and fragility.

Annicchiarico and Piergallini (2004) support the view that sound debt policies ground price stability, detailing the possible interrelations between monetary and fiscal policy and enforcing the plead for a fiscal convergence within the Euro area. Their findings show that a passive monetary policy (i.e. that does not satisfy the 'Taylor principle') may ensure determinacy in rational expectations equilibrium. Simulation results show that the combination of a generalized Taylor rule with low inertia and a public debt-GDP ratio target is the most desirable fiscalmonetary policy mix.

In a recent review, Regling et al. (2010) underline, on the one hand, that the first decade of economic and monetary union in Europe (EMU) has significantly benefited its member countries and accelerated the European integration process. On the other hand, those imbalances within EMU, such as differences in growth, inflation, competitiveness, current account and budget balances, have increased over the same period and enhance nowadays the economic implications, more evident in the global economic crisis.

Kenny and Morgan (2011) identify as key priority the need to extend existing tools and/or develop new tools to account for important feedback mechanisms, where improved real-financial links and nonlinear dynamics.

Giannone and Reichlin (2006) studied the synchronization of recessions within the Euro area countries and, based on similarities and differences with respect to the US case, found that persistent gaps in levels of income per capita have been registered since 1970, for the Euro area. Still, these gaps are small and business cycle characteristics, measured by levels of output, are very similar across countries. Furthermore, it is shown that output variance is mainly explained by common shocks with similar propagation mechanisms, whilst idiosyncratic shocks are small even if persistent. As such, the Euro area lags the US and its cycle is more persistent, but less volatile. Low growth, persistence of shocks and low volatility are common characteristics of the Euro area, and the gap with respect to the US has been stable over the last thirty years.

Castren and Kavonius (2009), by looking at the funds flow statistics among the Euro area countries, found that in the bilateral cross-sector exposures financial systems represent fundamental channels by means of which local risk exposures and balance sheet mismatching can be transmitted; a 
key role in the processes is played by the financial intermediaries. High financial leverage as well as high asset volatility are shown to increase the financial sector's vulnerability to shocks and contagion.

Peersman (2011) maintains that the EMU can stimulate the economy beyond the quantitative easing practice, respectively by means of the policy rate increasing the size of its balance sheet or the monetary base.

By using econometric methods such as Granger causality or panel-data regression, the researchers detect the interdependencies between the real economy and the financial market, considering the isolated influences of other factors as: effects of global financial crisis on monetary union and differences between Euro area countries, etc.

In the light of the reviewed literature, the researchers will develop their analysis starting from the hypothesis that, for the period of 2000-2011, within the Euro-12 member countries, there was no link between the stock market and the real economy (depicted by e.g. monetary policies and macroenomic growth) dynamics. The analysis starts by (i) describing the used data sample, (ii) testing for stationarity the selected time series and cointegration of variables, (iii) using a bivariate Granger causality test to determine the (non)existence of a relationship between stock market returns and economic growth and between stock market returns and interest rate, and (iv) constructing a VAR model for estimating the determined relationships.

Based on the obtained results and by using panel data and panel regression models, the researchers will further develop the study as to the following hypotheses:

(H1) There is a significant relationship between stock market and real economy;
(H2) The stock market performance is a predictor of the real economy;

(H3) The real economy is a predictor of stock market performances;

(H4) The stock market volatility is a predictor of economic growth;

(H5) The Euro area interest rate is a predictor of stock market volatility.

The results show the existence of a bidirectional causality between the stock market and monetary policy, while there is no causality between the stock market and real economic growth.

\section{Data Sample}

In order to investigate the relationship between the stock market and real economy for the Euro area countries, the following data series, sourced from the Eurostat database, were used:

- $\Delta G D P_{t}$ - Real economic growth of the Euro area countries (Euro-12: Austria, Belgium, Finland, France, Germany, Greece, Ireland, Italy, Luxembourg, the Netherlands, Portugal and Spain)

- $R_{t}$ - EURO STOXX 50 Index returns, Europe's leading Blue-chip index for the Euro area, provides a blue-chip representation of super sector leaders in the Euro-12.

$I R_{t}$ - Overall Euro area interest rate, i.e. EURIBOR at a one-month term.

The used data has quarterly periodicity covering the time period 2000-2011 and has been filtered for seasonality using TRAMO/SEATS procedure. All the computations were done using Eviews 5.0 software. 


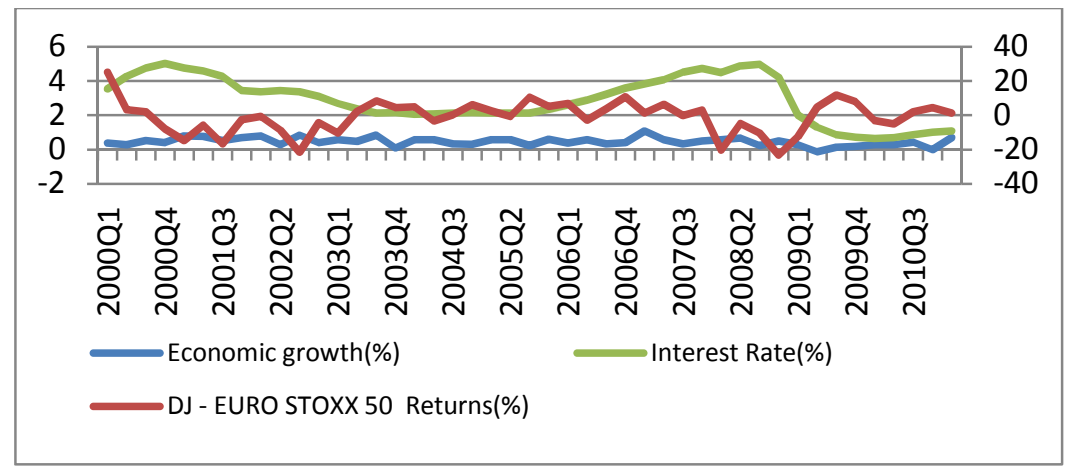

Figure 1: Quarterly Evolution of the Leading Indicators.

As could be seen from Figure 1, the financial and economic crisis had a severe impact on the economic growth of EURO12 area and also on stock market return.

The interest rate had a descending trend during the financial crisis, as a reaction from the European Central Bank to the turbulences of the Euro Zone.

\section{Testing for Stationarity}

In order to test the stationarity of the time series, Augmented Dickey-Fuller test was applied, with all the three variants (intercept only, trend and intercept, without trend and intercept).

The results are summarized below:

Table 1: Results of the Augmented Dickey-Fuller Stationarity Test

\begin{tabular}{|l|l|l|l|l|l|l|}
\hline & \multicolumn{2}{|l|}{$R_{t}$} & \multicolumn{2}{l|}{$\Delta G D P_{t}$} & \multicolumn{2}{l|}{$I R_{t}$} \\
\hline$H_{0}:$ unit root & $\begin{array}{l}\text { ADF } \\
\text { Statistic }\end{array}$ & $\begin{array}{l}\text { P- } \\
\text { value }\end{array}$ & $\begin{array}{l}\text { ADF } \\
\text { Statistic }\end{array}$ & $\begin{array}{l}\text { P- } \\
\text { value }\end{array}$ & $\begin{array}{l}\text { ADF } \\
\text { Statistic }\end{array}$ & $\begin{array}{l}\text { P- } \\
\text { value }\end{array}$ \\
\hline Intercept & -4.86 & 0.00 & -4.86 & 0.00 & -2.950 & 0.052 \\
\hline $\begin{array}{l}\text { Trend } \\
\text { intercept }\end{array}$ & -4.96 & 0.00 & -4.96 & 0.00 & -2.257 & 0.443 \\
\hline None & -4.87 & 0.00 & -4.87 & 0.00 & -1.336 & 0.164 \\
\hline
\end{tabular}

ADF statistics indicates a clear rejection of unit root hypothesis in the case of EUROSTOXX returns and real economic growth, the conclusion can thus be that both series are stationary; yet, the overall interest rate is non-stationary.

\section{Cointegration}

Since only the overall interest rate is a nonstationary series (resulting be a I(1) series), the researchers performed a cointegration analysis between $R_{t}$ and $I R_{t}$ in order to detect a long-run relationship. 
Table 2: Results of the Cointegration Analysis for the Non-Stationary Variables

\begin{tabular}{|c|c|c|c|c|c|}
\hline \multicolumn{6}{|c|}{ Information Criteria by Rank and Model } \\
\hline Data Trend: & None & None & Linear & Linear & Quadratic \\
\hline \multirow[t]{2}{*}{$\begin{array}{l}\text { Rank or No. } \\
\text { of CEs }\end{array}$} & No Intercept & Intercept & Intercept & Intercept & Intercept \\
\hline & No Trend & No Trend & No Trend & Trend & Trend \\
\hline \multicolumn{6}{|c|}{ Log Likelihood by Rank (rows) and Model (columns) } \\
\hline 0 & -89.491 & -89.491 & -89.319 & -89.319 & -85.622 \\
\hline 1 & -81.514 & -81.479 & -81.447 & -80.720 & -77.065 \\
\hline 2 & -81.225 & -79.151 & -79.151 & -76.010 & -76.010 \\
\hline \multicolumn{6}{|c|}{ Akaike Information Criteria by Rank (rows) and Model (columns) } \\
\hline 0 & 6.233 & 6.233 & 6.355 & 6.355 & 6.241 \\
\hline 1 & 5.968 & 6.032 & 6.096 & 6.115 & $5.937643^{*}$ \\
\hline 2 & 6.215 & 6.210 & 6.210 & 6.134 & 6.134 \\
\hline \multicolumn{6}{|c|}{ Schwarz Criteria by Rank (rows) and Model (columns) } \\
\hline 0 & 6.420 & 6.420 & 6.635 & 6.635 & 6.615 \\
\hline 1 & $6.341229 *$ & 6.452 & 6.564 & 6.628 & 6.498 \\
\hline 2 & 6.775 & 6.864 & 6.864 & 6.881 & 6.881 \\
\hline
\end{tabular}

As the cointregration analysis results show, there is one significant cointegration relationship between the aggregated stock market returns and the overall Euro area interest rate, suggesting the existence of a link between the monetary policy and stock market dynamics.

\section{Granger Causality}

The existence of a long term relationship between stock market returns and economic growth (also between stock market returns and interest rate) is determined by using a bivariate Granger causality test. Granger causality between two variables refer to how past values of a variable can be used to explain the values of the other variables.

In the present case, Granger causality test is reduced to estimate the following regression models:

$$
\begin{gathered}
\Delta G D P_{t}=\alpha_{0}+\alpha_{1} \Delta G D P_{t-1}+\ldots+\alpha_{l} \Delta G D P_{t-l}+\beta_{1} R_{t-1}+\ldots+\beta_{l} R_{t-l}+\varepsilon_{t} \\
R_{t}=\alpha_{0}+\alpha_{1} R_{t-1}+\ldots+\alpha_{l} R_{t-l}+\beta_{1} \Delta G D P_{t-1}+\ldots+\beta_{l} \Delta G D P_{t-l}+u_{t} \\
I R_{t}=\alpha_{0}+\alpha_{1} I R_{t-1}+\ldots+\alpha_{l} I R_{t-l}+\beta_{1} R_{t-1}+\ldots+\beta_{l} R_{t-l}+\varepsilon_{1 t} \\
R_{t}=\alpha_{0}+\alpha_{1} R_{t-1}+\ldots+\alpha_{l} R_{t-l}+\beta_{1} I R_{t-1}+\ldots+\beta_{l} I R_{t-l}+u_{1 t}
\end{gathered}
$$

The null hypothesis is $H_{0}: \beta_{1}=\ldots=\beta_{l}=0$; in the first case, tested is if $R_{t}$ Granger cause $\Delta G D P_{t}$ (or
$I R_{t}$ ), while in the second case it is tested if $\Delta G D P_{t}\left(\right.$ or $I R_{t}$ ) Granger cause $R_{t}$. 
Table 3: Granger Causality Tests for $l=2$

\begin{tabular}{|l|l|l|l|}
\hline $\begin{array}{l}\text { Granger } \\
\text { causality }\end{array}$ & Null hypothesis & $\begin{array}{l}\text { F- } \\
\text { statistic }\end{array}$ & $\begin{array}{l}\text { P- } \\
\text { value }\end{array}$ \\
\hline$\Delta G D P_{t} \rightarrow R_{t}$ & $\Delta G D P_{t}$ does not Granger cause $R_{t}$ & 0.045 & 0.833 \\
\hline$R_{t} \rightarrow \Delta G D P_{t}$ & $R_{t}$ does not Granger cause $\Delta G D P_{t}$ & 0.175 & 0.678 \\
\hline$I R_{t} \rightarrow R_{t}$ & $I R_{t}$ does not Granger cause $R_{t}$ & 9.893 & 0.003 \\
\hline$R_{t} \rightarrow I R_{t}$ & $R_{t}$ does not Granger cause $I R_{t}$ & 26.908 & 0.000 \\
\hline
\end{tabular}

The results of Granger causality test show the existence of a bi-directional causality between stock market and monetary policy, whilst there is no causality between stock market and real economic growth.

\section{VAR Model for Estimating the Relationship between Stock Market and Macroeconomic Indicators}

In order to evaluate the intensity and the direction of the causality relationship between stock market and macroeconomic indicators, the researchers estimated the following $\operatorname{VAR}(\mathrm{p})$ model:

$$
Y_{t}=A_{1} Y_{t-1}+\ldots+A_{p} Y_{t-p}+B d_{t}+\varepsilon_{t} \text {, }
$$

Where $Y_{t}=\left(\Delta G D P_{t} R_{t} I R_{t}\right)^{\prime} \quad$ is the vector of the variable analyzed, $\varepsilon_{t}$ is a vector of innovations and $d_{t}$ is a dummy variable which captures the effect of financial crisis $\left(d_{t}=1\right.$ for the period 2008-2011 and $d_{t}=0$ otherwise). For estimation, a VAR(2) was chosen, based on the lag length tests (Akaike Information Criteria, Hannah-Quinn). The VAR(2) model has the following specification:

$$
\left\{\begin{array}{c}
\Delta G D P_{t}=\alpha_{10}+\alpha_{11} \Delta G D P_{t-1}+\alpha_{12} \Delta G D P_{t-2}+ \\
\quad+\beta_{11} R_{t-1}+\beta_{12} R_{t-2}+\gamma_{11} I R_{t-1}+\gamma_{12} I R_{t-2}+b_{1} d_{t}+\varepsilon_{1 t} \\
R_{t}=\alpha_{20}+\alpha_{21} \Delta G D P_{t-1}+\alpha_{22} \Delta G D P_{t-2}+ \\
\quad+\beta_{21} R_{t-1}+\beta_{22} R_{t-2}+\beta_{23} R_{t-3}+\beta_{44} R_{t-4}+\gamma_{21} I R_{t-1}+\gamma_{22} I R_{t-2}+b_{2} d_{t}+\varepsilon_{2 t} \\
I R_{t}=\alpha_{30}+\alpha_{31} \Delta G D P_{t-1}+\alpha_{32} \Delta G D P_{t-2}+ \\
\quad+\beta_{31} R_{t-1}+\beta_{32} R_{t-2}+\gamma_{31} I R_{t-1}+\gamma_{32} I R_{t-2}+b_{3} d_{t}+\varepsilon_{3 t}
\end{array}\right.
$$

The researchers also estimated a VAR(2) model without the crisis dummy, in order to asses the significance of the financial crisis on the relationship between stock market and real economy. 
Table 4: Estimation Results of VAR(2) - * Statistically Significant at 95\%.

\begin{tabular}{|l|l|l|l|l|l|l|}
\hline & \multicolumn{3}{|l|}{ Model with crisis dummy } & \multicolumn{3}{l}{ Model without crisis dummy } \\
\hline & $R_{t}$ & $\Delta G D P_{t}$ & $I R_{t}$ & $R_{t}$ & $\Delta G D P_{t}$ & $I R_{t}$ \\
\hline$R_{t-1}$ & 0.168 & -0.002 & $0.163^{*}$ & 0.301 & 0.001 & $0.171^{*}$ \\
\hline$R_{t-2}$ & 0.067 & -0.002 & -0.007 & 0.157 & 0.000 & 0.047 \\
\hline$\Delta G D P_{t-1}$ & 0.907 & $-0.360^{*}$ & 0.445 & 0.695 & -0.217 & $0.481^{*}$ \\
\hline$\Delta G D P_{t-2}$ & -2.406 & -0.177 & -0.038 & 3.436 & -0.039 & -0.371 \\
\hline$I R_{t-1}$ & $-0.074^{*}$ & $0.002^{*}$ & $1.472^{*}$ & -0.069 & $0.246^{*}$ & $1.475^{*}$ \\
\hline$I R_{t-2}$ & 0.037 & -0.002 & $-0.546^{*}$ & 0.038 & -0.14 & $-0.545^{*}$ \\
\hline Intercept & $11.867^{*}$ & $0.555^{*}$ & 1.095 & 2.451 & $0.331^{*}$ & -4.535 \\
\hline Crisis dummy & $-8.173^{*}$ & $-0.194^{*}$ & -4.887 & & & \\
\hline$R^{2}$ & 0.487 & 0.410 & 0.967 & 0.390 & 0.339 & 0.967 \\
\hline$R_{a d j}^{2}$ & 0.385 & 0.292 & 0.960 & 0.289 & 0.229 & 0.961 \\
\hline F-statistic & 4.751 & 3.477 & 146.841 & 3.840 & 3.075 & 175.422 \\
\hline
\end{tabular}

There are significant differences between the results of the estimated models in terms of the impact of the financial crisis. Firstly, for the model without the crisis effect, there is only a positive unidirectional causality, from stock market return to interest rate. From this point of view, for the entire analyzed period, without isolating the effect of the financial crisis, there is no significant causality from the monetary policy or real economic growth to stock market return. Secondly, after introducing the dummy variable in order to isolate the effect of financial crisis, the model shows a bi-directional causality between stock market return and interest rate. This can lead to the conclusion that there may exist a direct influence of the financial crisis on the relationship between stock market and monetary policy: during the financial crisis, stock market return seemed to be irresponsive to the dynamics of monetary policy. Consequently, from both models, it can be deduced there is no significant relationship between stock market return and real economic growth.
The method used in this paper by introducing the crisis dummy variable is very useful in order to control for the effects of the financial crisis.

\section{Relationship between Stock Market and Real Economy Using Panel Data}

In order to investigate the relationship between stock market and real economy for Euro area countries, a panel data analysis was performed using the following variables for the period 2000-2011:

- $\Delta G D P_{t}$ - Real economic growth, quarterly data, provided for each country by EUROSTAT,

- $I R_{t}$ - Overall Euro area interest rate,

- $\quad R_{t}=\log P_{t}-\log P_{t-1} \quad$ - $\quad$ Daily logreturns for stock market indexes, data provided by Bloomberg, 
- $\sigma_{t}$ - Daily volatilities for each stock market index, computed using daily logreturns data.

Since real GDP growth has a quarterly periodicity, daily log-returns and daily volatilities were transformed into quarterly ones. Quarterly log-return was computed as an average of daily log-returns; also, a quarterly volatility was estimated using the following relation:

$\sigma_{\text {QUARTERLY }}=\sqrt{60} \sigma_{\text {DAILY }}$, assuming that a full transaction year has approximately 240 days.

Table 5: Country Stock Market Indexes

\begin{tabular}{|l|l|}
\hline Country & Stock Market Index \\
\hline Netherlands & AEX \\
\hline Greece & ASE \\
\hline Austria & ATX20 \\
\hline Belgium & BEL20 \\
\hline France & CAC40 \\
\hline Italy & FTSEMIB \\
\hline Spain & IBEX \\
\hline Ireland & ISEQ \\
\hline Luxemburg & LUXX \\
\hline Finland & OMXH15 \\
\hline Portugal & PSI20 \\
\hline
\end{tabular}

\section{Panel Data Regression Models}

Using the variables described above, one can estimate a simple panel data regression in order to asses the impact of financial crisis on the relationship between the stock market and macroeconomic variables for the Euro area countries.

The model has the following expression:

$$
y_{i t}=\alpha+X_{i t}^{\prime} \beta+c_{i} d_{i t}+v_{i t}
$$

Where $y_{i t}$ is the dependent variable, $X_{i t}$ is a matrix of explanatory variables, $v_{i t} \sim$ $I I D\left(0, \sigma_{v}^{2}\right), d_{i t}$ is a dummy variable which captures the effect of financial crisis ( $d_{i t}=1$ for the period 2008-2011 and $d_{i t}=0$ otherwise). It is noted that the index $i$ refers to country, while the index $t$ refers to time-period.
With this model, one can evaluate the relationship between stock market and macroeconomic variables through the $\beta$ coefficient of explanatory variables $X_{i t}$; also, the coefficient of the dummy variable $d_{i t}$ could give an indication whether the financial crisis had a significant impact on this relationship for each country.

\section{Stock Market Performance as a Predictor of the Real Economy}

In order to asses the correlation between stock market performances and real economy, the following model is conceived,

$$
\Delta G D P_{i t}=\alpha+R_{i t-1}^{\prime} \beta+c_{i} d_{i t}+v_{i t}
$$

Where $i=1 \ldots 12$ represents the country and $t$ is the time index. 
Table 6: Stock Market Performance and the Real Economy

\begin{tabular}{|l|l|l|l|l|}
\hline Variable & Coefficient & Std. Error & t-Statistic & Prob. \\
\hline C & 0.628 & 0.050 & 12.508 & 0.000 \\
R?(-1) & 0.025 & 0.009 & 2.948 & 0.003 \\
\hline Crisis dummy & & & & \\
\hline Austria & -0.310 & 0.218 & -1.424 & 0.155 \\
Belgium & -0.372 & 0.194 & -1.915 & 0.056 \\
Finland & -0.709 & 0.472 & -1.502 & 0.134 \\
France & -0.595 & 0.137 & -4.327 & 0.000 \\
Germany & -0.492 & 0.322 & -1.528 & 0.127 \\
Greece & -1.145 & 0.300 & -3.816 & 0.000 \\
Ireland & -1.386 & 0.343 & -4.035 & 0.000 \\
Italy & -0.846 & 0.223 & -3.787 & 0.000 \\
Luxembourg & -0.265 & 0.579 & -0.457 & 0.648 \\
Netherlands & -0.570 & 0.165 & -3.462 & 0.001 \\
Portugal & -0.719 & 0.162 & -4.429 & 0.000 \\
Spain & -0.779 & 0.143 & -5.452 & 0.000 \\
\hline R-squared & 0.226 & Mean dependent var & & 0.410 \\
Adjusted R-squared & 0.207 & S.D. dependent var & & 1.085 \\
S.E. of regression & 0.966 & Akaike info criterion & & 2.794 \\
Sum squared resid & 488.001 & Schwarz criterion & & 2.906 \\
Log likelihood & -736.280 & F-statistic & & 11.772 \\
Durbin-Watson stat & 1.951 & Prob(F-statistic) & & 0.000 \\
\hline
\end{tabular}

As one can notice, the estimated model is valid and the influence of stock market performance is statistically significant. There is a direct, significant relationship between capital market performance and macroeconomic developments. The sensible way of explaining this relationship is that it begins from the stock market towards the real economy with a delay of one quarter. For most of the countries in the Euro area, the financial crisis had a significant impact on this relationship, with the highest influence for Ireland, Greece, Italy, Portugal and Spain. There are also few countries for which this relationship is not affected by the financial crisis: Austria,
Belgium, Finland, Germany and Luxembourg.

\section{Real Economy as a Predictor of Stock Market Performances}

In order to asses the ability of real economic growth to predict stock market performances, the following model is estimated:

$$
R_{i t}=\alpha+\Delta G D P_{i t-1}^{\prime} \beta+c_{i} d_{i t}+v_{i t}
$$

Where $i=1 \ldots 12$ represents the country and $t$ is the time index. 
Table 7: Real Economy as a Predictor of Stock Market Performances

\begin{tabular}{|c|c|c|c|c|}
\hline Variable & Coefficient & Std. Error & t-Statistic & Prob. \\
\hline $\mathrm{C}$ & 0.102 & 1.438 & 0.071 & 0.944 \\
\hline DGDP?(-1) & 0.897 & 0.906 & 0.989 & 0.323 \\
\hline \multicolumn{5}{|l|}{ Crisis dummy } \\
\hline Austria & -4.149 & 4.520 & -0.918 & 0.359 \\
\hline Belgium & -3.611 & 3.098 & -1.166 & 0.244 \\
\hline Finland & -4.716 & 3.517 & -1.341 & 0.181 \\
\hline France & -2.704 & 2.820 & -0.959 & 0.338 \\
\hline Germany & -2.465 & 3.454 & -0.714 & 0.476 \\
\hline Greece & -8.064 & 3.719 & -2.168 & 0.031 \\
\hline Ireland & -4.364 & 2.815 & -1.550 & 0.122 \\
\hline Italy & -3.477 & 2.510 & -1.385 & 0.167 \\
\hline Luxembourg & -6.107 & 7.464 & -0.818 & 0.414 \\
\hline Netherlands & -3.212 & 3.606 & -0.891 & 0.373 \\
\hline Portugal & -4.023 & 3.795 & -1.060 & 0.290 \\
\hline Spain & -4.106 & 3.379 & -1.215 & 0.225 \\
\hline R-squared & 0.056 & Mean dependent var & -0.831 & \\
\hline Adjusted R-squared & 0.033 & S.D. dependent var & 11.158 & \\
\hline S.E. of regression & 10.972 & Akaike info criterion & 7.654 & \\
\hline Sum squared resid & 63083.170 & Schwarz criterion & 7.766 & \\
\hline Log likelihood & -2044.999 & F-statistic & 2.410 & \\
\hline Durbin-Watson stat & 1.305 & Prob (F-statistic) & 0.004 & \\
\hline
\end{tabular}

For the entire Euro-12 area, the influence of real economic growth on stock market return is not significant, a conclusion cannot be reached about the impact of the financial crisis; yet, for Greece, the coefficient of the crisis dummy variable is significant, which means that this country had a different behavior than the Euro area as a whole.
Stock Market Volatility as a Predictor of Economic Growth

In order to assess the ability of the stock market risk (measured by volatility) to predict real economic growth, the following model is estimated,

$\Delta G D P_{i t}=\alpha+\sigma_{i t-1}^{\prime} \beta+c_{i} d_{i t}+v_{i t}$

Where $i=1 \ldots 12$ represents the country and $t$ is the time index. 
Table 8: Stock Market Volatility as a Predictor of Economic Growth

\begin{tabular}{|l|l|l|l|l|}
\hline Variable & Coefficient & Std. Error & $\begin{array}{l}\text { t- } \\
\text { Statistic }\end{array}$ & Prob. \\
\hline C & 1.266 & 0.191 & 6.620 & 0.000 \\
VOL?(-1) & -6.575 & 2.074 & -3.169 & 0.002 \\
\hline Crisis dummy & & & & \\
\hline Austria & -0.026 & 0.222 & -0.119 & 0.906 \\
Belgium & -0.319 & 0.181 & -1.760 & 0.079 \\
Finland & -0.559 & 0.428 & -1.308 & 0.192 \\
France & -0.445 & 0.146 & -3.037 & 0.003 \\
Germany & -0.387 & 0.291 & -1.329 & 0.185 \\
Greece & -0.926 & 0.324 & -2.856 & 0.005 \\
Ireland & -1.128 & 0.288 & -3.915 & 0.000 \\
Italy & -0.698 & 0.187 & -3.742 & 0.000 \\
Luxembourg & -0.147 & 0.547 & -0.269 & 0.788 \\
Netherlands & -0.447 & 0.124 & -3.622 & 0.000 \\
Portugal & -0.487 & 0.273 & -1.787 & 0.075 \\
Spain & -0.604 & 0.151 & -3.996 & 0.000 \\
\hline R-squared & 0.259 & Mean dependent var & 0.415 & \\
Adjusted R-squared & 0.239 & S.D. dependent var & 1.097 & \\
S.E. of regression & 0.956 & Akaike info criterion & 2.776 & \\
Sum squared resid & 454.612 & Schwarz criterion & 2.892 & \\
Log likelihood & -695.203 & F-statistic & 13.340 & \\
Durbin-Watson stat & 1.971 & Prob(F-statistic) & 0.000 & \\
\hline
\end{tabular}

As the model is valid, one can infer that the stock market volatility could be seen as a predictor of the real economic growth. A higher volatility has a negative impact on macroeconomic developments, which could be explained by an increasing level of uncertainty about the stock markets, which would cause leaks of capital and low market liquidity levels, reflected in the real economy through the consumption channel. The impact of the financial crisis on the influence of stock market volatility on real economic growth is significant only for a small group of countries: Greece, Italy, Spain, Netherlands, France and Ireland. The highest influence of financial crisis is for Ireland $(-1.12 \%)$ and Greece $(-0.9 \%)$.

\section{Euro Area Interest Rate as a Predictor of Stock Market Volatility}

In order to asses the ability of the economic growth to predict stock market risk, the following model is formulated,

$$
\sigma_{i t}=\alpha+I R_{i t-1}^{\prime} \beta+c_{i} d_{i t}+v_{i t}
$$

Where $i=1 \ldots 12$ represents the country and $t$ is the time index. 
Table 9: Euro Area Interest Rate as a Predictor of Stock Market Volatility

\begin{tabular}{|l|l|l|l|l|}
\hline Variable & Coefficient & Std. Error & $\begin{array}{l}\text { t- } \\
\text { Statistic }\end{array}$ & Prob. \\
\hline C & 0.026 & 0.019 & 1.358 & 0.175 \\
IR?(-1) & 0.020 & 0.006 & 3.190 & 0.002 \\
\hline Crisis dummy & & & & \\
\hline Austria & 0.093 & 0.024 & 3.886 & 0.000 \\
Belgium & 0.056 & 0.017 & 3.380 & 0.001 \\
Finland & 0.073 & 0.017 & 4.242 & 0.000 \\
France & 0.070 & 0.020 & 3.522 & 0.001 \\
Germany & 0.061 & 0.020 & 3.067 & 0.002 \\
Greece & 0.106 & 0.017 & 6.069 & 0.000 \\
Ireland & 0.091 & 0.019 & 4.777 & 0.000 \\
Italy & 0.075 & 0.020 & 3.689 & 0.000 \\
Luxembourg & 0.068 & 0.018 & 3.731 & 0.000 \\
Netherlands & 0.066 & 0.021 & 3.163 & 0.002 \\
Portugal & 0.088 & 0.037 & 2.352 & 0.019 \\
Spain & 0.078 & 0.019 & 4.016 & 0.000 \\
\hline R-squared & 0.362 & Mean dependent var & 0.103 & \\
Adjusted R-squared & 0.345 & S.D. dependent var & 0.058 & \\
S.E. of regression & 0.047 & Akaike info criterion & -3.265 & \\
Sum squared resid & 1.093 & Schwarz criterion & -3.150 & \\
Log likelihood & 856.363 & F-statistic & 21.879 & \\
Durbin-Watson stat & 1.174 & Prob(F-statistic) & 0.000 & \\
\hline & & & & \\
\hline
\end{tabular}

The impact of overall interest rate on stock market volatility is positive, a shock of monetary policy having a response of the same sign from stock market volatility. All the countries exhibit the same behavior during the financial crisis; the most affected country being again Greece.

\section{Conclusions}

This study's sample is based on quarterly observations within the Euro-12 area, of variables such as GDP growth, aggregate interest rates and of stock market returns of top blue-chip company operating within the region. The initial findings suggest the existence of a link between the monetary policy and stock market dynamics and a bidirectional causality between stock market and monetary policy, while there is no causality between stock market and real economic growth. Moreover, during the financial crisis, stock market return seems to be irresponsive to the dynamics of monetary policy. This result is in line with the existing literature, which underlines a lag in adaption of the ad-hoc interest rate and monetary policy measures with limited effect on a short term.

The researchers found no significant relationship between stock market return and real economic growth. Possible explanations for this would be that the stock market does mean just a small part of real economy, and not necessarily the keypart; on the other hand, economic growth means more investors who finally get the same pie, which means a smaller bite for each of them-- therefore a miscorrelation 
between the trend of the economy and the yield trend. Also, economic growth is linked to dividends and expected returns on the medium and long term, while the return is a function depending on three factors: the initial value of the stock, the expected dividend and the market value of the stock. Accordingly, this is not the same sort of aspects which influence the economic growth and the stock market returns.

Furthermore, as observed based on the analyzed information dating up to year 2011 , the impact of overall interest rate on stock market volatility is positive, a shock of monetary policy having a response of the same sign from stock market volatility. Higher interest rates dry up stock markets liquidity in the Euro zone. That is very interesting because, as compared to the US, Europe decided to keep interest rates high, as such shutting the door for liquidity on the equity markets. Furthermore, interesting enough, the main target of central banks is the price stability; keeping inflation below 2\%. At the same time, the same central banks and regulators put pressure on the banks to boost liquidity, local markets are frozen and the liquidity from stock markets is just not there. This in the end leaves us with a messy, not at all focused monetary policy approach up to 2011, which appears to be corrected during 2012 as per the latest European reference interest rates reductions. For Euro area countries as a whole, the impact of real economic growth on stock market volatility is similar to the impact of volatility on economic growth. The highest influence of the financial crisis is for Greece, with almost 7\% increase in volatility.

Based on the tested validity of the model, it can be infered that the stock market volatility could be seen as a predictor of the real economic growth. A higher volatility has a negative impact on macroeconomic developments, which could be explained by an increasing level of uncertainty on the stock markets, which would cause leaks of capital and low market liquidity levels, reflected in the real economy through the consumption channel. Regarding the impact of the financial crisis on the influence of stock market volatility on real economic growth, this is significant only for a small group of countries: Greece, Italy, Spain, Netherlands and Ireland. The highest influence of financial crisis is for Ireland ($1.12 \%)$ and Greece (-0.9\%).

The researchers drew a map based on the coefficient of the dummies resulted from the volatility-economic growth relationship and, one can notice clearly a group of countries- Ireland, Greece, Italy, Spain and Portugal, where the crisis had the major impact on this relationship. 


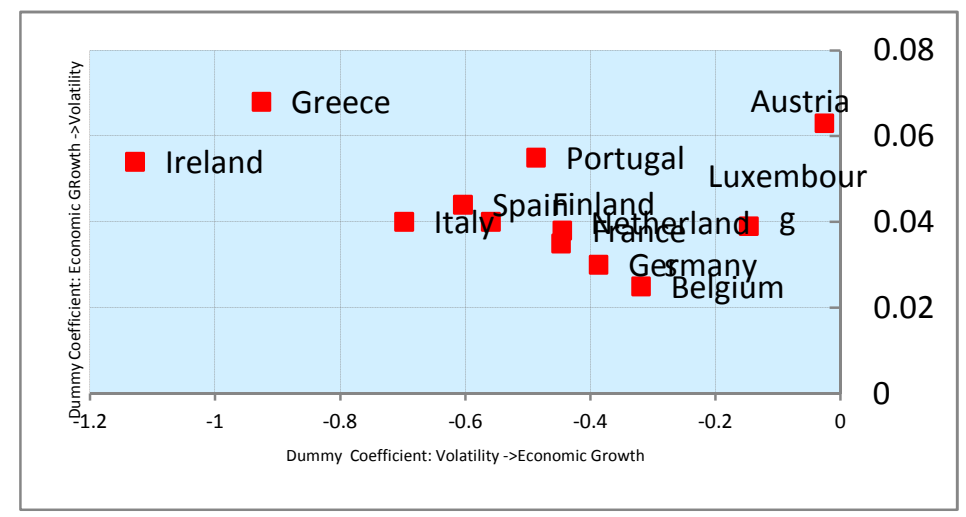

Figure 2. Map of the Volatility-Economic Growth Relationship

The researchers have tested the relationship for other variable, such as: unemployment rate, inflation rate, banking liquidity ratio, but the results indicated that their correlation with the stock market indicators (return and volatility) is not significant.

It was decided by the researchers to estimate the panel-data regression for each country because if the coefficient of that dummy were to be significant, that would mean for that country the crisis had a significant impact on the relationship between the considered variables. Granger was not tested causally in panel data- this is going to be the next step of this research, when it is intended to capture the relationship for the whole EU-27, taking into consideration some other factors like: investors' sentiments and uncertainty level measures, as well as other methodologies (Autoregressive Distributed Lags- ARDL, Vector Error Correction Model- VECM).

\section{Acknowledgement}

The authors of this paper would like to thank Prof. Anghelache Gabriela for the support and advice on the setting of the research sample and methodology.

\section{References}

Annicchiarico, B., Marini, G. \& Piergallini, A. (2004). "Monetary Policy and Fiscal Rules," CEIS Tor Vergata - Research Paper Series, Vol.17, No. 50.
Bartram, S. M., Taylor, S. J. \& Wang, Y. H. (2007). "The Euro and European Financial Market Dependence,"

Bjornland, H. C. \& Leitemo, K. (2009). "Identifying the Interdependence between US Monetary Policy and the Stock Market," Journal of Monetary Economics, Vol. 56 (2), March 2009, p. 275-282, ISSN 0304-3932.

Cardarelli, R., Elekdag, S. \& Kose, M. A. (2010). "Capital Inflows: Macroeconomic Implications and Policy Responses," Economic Systems, Vol. 34, pp. 333-356.

Castrén, O. \& Kavonius, I. K. (2009). "Balance Sheet Interlinkages and MacroFinancial Risk Analysis in the Euro Area," European Central Bank Working Paper Series, No 1124.

Dimitrova, D. (2005). "The Relationship between Exchange Rates and Stock Prices: Studied in a Multivariate Model," Issues in Political Economy, Vol. 14, August 2005.

Forster, K., Vasardani, M. A. \& Ca'Zori, M. (2011). "Euro Area Cross-Border Financial Flows and the Global Financial Crisis," European Central Bank, Occasional Paper Series, No.126.

Furceri, D., Guichard, S. \& Rusticelli, E. (2011). Episodes of Large Capital Inflows and the Likelihood of Banking and Currency Crises and Sudden Stops, Working Paper Series, No 865, OECD Economics Department. 
Giannellis, N., Papadopoulos, A. \& Kanas, A. (2008). "Asymmetric Volatility Spillovers between Stock Market and Real Activity: Evidence from UK and US, Working Papers 0807," University of Crete, Department of Economics.

Giannone, D. \& Reichlin, L. (2006). “Trends and Cycles in the Euro Area. How Much Heterogeneity and Should We Worry about it," European Central Bank, Working Papers Series, No. 595.

Jamil, M. (2010). 'Impact of Financial Market Developments and Stock Markets Volatility on Economic Growth: A Dynamic Panel Data Analysis,' Working Paper, University of Viena.

Junttila, J. \& Korhonen, M. (2011). “Utilizing Financial Market Information in Forecasting Real Growth, Inflation and Real Exchange Rate," International Review of Economics \& Finance, Volume 20, Issue 2, Heckscher-Ohlin Theory: A Modern Approach, April 2011, Pages 281-301.

Kenny, G. \& Morgan, J. B. (2011). "Some Lessons from the Financial Crisis for the Economic Analysis," European Central Bank, Ocassional Working Papers Series, No. 130.

Kilian, L. \& Park, C. (2009). "The Impact Of Oil Price Shocks On The U.S. Stock Market" International Economic Review, 50: 12671287.

Milani, F. (2011). "The Impact of Foreign Stock Markets on Macroeconomic Dynamics in Open Economies: A Structural Estimation," Journal of International Money and Finance, Elsevier, vol. 30 (1), p. 111129.

Næs, R., Skjeltorp, J. A. \& Ødegaard, B. A. (2011). "Stock Market Liquidity and the Business Cycle," Journal of Finance, forthcoming 2011, http://www.afajof.org/journal/forth_abstr act.asp?ref $=623$
Nowbutsing, B. M. \& Odit, M. P. (2009). "Stock Market Development And Economic Growth: The Case of Mauritius," International Business \& Economics Research Journal, Vol 8, no. 2 (2009).

Ostry, J. D., Ghosh, A. R., Habermeier, K., Chamon, M., Qureshi, M. S. \& Reinhard, D. B. S. (2010). "Capital Inflows: The Role of Controls," IMF Staff Position Note, No SPN/10/04.

Peersman, G. (2011). "Macroeconomic Effects of Unconventional Monetary Policy in the Euro Area," Monetary Policy and International Finance Journal, CESIFO Working Paper No 3589.

Raunig, B. \& Scharler, J. (2010). 'Stock Market Volatility and the Business Cycle, Monetary Policy \& the Economy,' Oesterreichische Nationalbank (Austrian Central Bank), issue 2, p. 54-63, July.

Regling, K., Deroose, S., Felke, R. \& Kutos, P. (2010). "The Euro After Its First Decade: Weathering the Financial Storm and Enlarging the Euro Area," Asian Development Bank Institute, Research Paper Series, No. 205.

Shahbaz, M., Ahmed, N. \& Ali, L. (2008). Stock Market Development and Economic Growth: ARDL Causality in Pakistan, Int. Res. J. Fin. Econ., 14: 182195.

Singh, A. (2008). Stock Markets in Low and Middle Income Countries, ESRC Centre for Business Research - Working Papers wp377, ESRC Centre for Business Research, Cambridge University.

Tepus, A. \& Toader A. (2011). 'The Relationship between Key Economic Indicators of the Euro Area after the Financial Crisis,' research paper presentation at the 17th IBIMA conference, Milan, Italy, 14-15 November. 